NBER WORKING PAPER SERIES

\title{
INSURANCE RATIONING AND THE ORIGINS OF WORKERS' COMPENSATION
}

Price V. Fishback

Shawn Everett Kantor

Working Paper No. 4943

\section{NATIONAL BUREAU OF ECONOMIC RESEARCH 1050 Massachusetts Avenue Cambridge, MA 02138 \\ December 1994}

The authors are grateful to Mark Isaac, Jeff LaFrance, Patrick Legros, Ron Oaxaca, Jim Ratliff, Stan Reynolds, and Joseph Terza for helpful comments and discussions. We have benefited from the insightful comments of seminar participants at Arizona, Georgia, Hawaii, Illinois, Indiana, North Carolina State, the National Bureau of Economic Research, and the Fall 1993 All-UC Economic History Conference. We also thank Claudia Goldin for her occupational codes to the BLS's 1917-1919 Cost-of-Living survey data used in this paper and Martha Olney who provided supplemental information about the BLS data. The BLS data were made available by the InterUniversity Consortium for Political and Social Research (No. 8299). This research has been supported by National Science Foundation Grant No. SBR-9223058. Responsibility for the interpretations and shortcomings of the paper remains ours. This paper is part of NBER's research program in the Historical Development of the American Economy. Any opinions expressed are those of the authors and not those of the National Bureau of Economic Research.

(C) 1994 by Price V. Fishback and Shawn Everett Kantor. All rights reserved. Short sections of text, not to exceed two paragraphs, may be quoted without explicit permission provided that full credit, including (c) notice, is given to the source. 


\title{
INSURANCE RATIONING AND THE \\ ORIGINS OF WORKERS' \\ COMPENSATION
}

\begin{abstract}
A central question concerning the economic motivation for the adoption of workers' compensation is the extent to which workers had access to their desired levels of private accident insurance around the turn of the century. If insurance were rationed then workers' primary option would have been to use savings to protect against accident risk. We develop a theoretical model that suggests that workers' compensation, under this market condition, should have caused a reduction in households' precautionary saving. Our empirical test is based on a sample of over 7000 households surveyed for the 1917-1919 Bureau of Labor Statistics Cost-of-Living study. Regression analysis suggests that households tended to save less, holding all else constant, if their states had workers' compensation in force. This finding, in concert with qualitative information about the insurance industry, provides some evidence that insurance companies were unable to effectively offer workplace accident insurance to a wide range of workers. By shifting the burden of insurance from workers to employers, workers' compensation benefitted risk-averse workers who were rationed out of the insurance market, even if they paid for their more generous post-accident benefits through lower wages.
\end{abstract}

Price V. Fishback

Department of Economics

University of Arizona

Tucson, AZ 85721

and NBER

\author{
Shawn Everett Kantor \\ Department of Economics \\ University of Arizona \\ Tucson, AZ 85721 \\ and NBER
}




\section{Insurance Rationing and the Origins of Workers' Compensation}

Over the last century the United States and many other countries have implemented a wide variety of social protection programs, including social security, unemployment insurance, workers' compensation, and government-subsidized health care. Costs have escalated in many of these programs, raising calls for large-scale reforms. In considering how to reform these programs, however, it is important to examine their origins. The original problems addressed by these social insurance schemes often determined how they were structured, which in turn influenced the programs' later paths of development. Most of the changes in our major social insurance programs since their inception have been evolutionary rather than revolutionary. This paper studies the origins of workers' compensation, which has experienced substantial cost increases over the past two decades, rising even faster than health care costs (Fefer 1992). Numerous reforms have been offered, including proposals to shift more of the financial burden of workplace accidents onto workers. ${ }^{1}$

Workers' compensation is often described as the first example of widespread social insurance in the United States (Weinstein 1967; Lubove 1967). In most states, however, guaranteed accident compensation was not achieved by establishing mandatory government insurance funds. Instead, workers' compensation laws shifted the liability for workplace accidents from negligence to a form of strict liability. The adoption of the new legal standard sharply increased the average amounts of postaccident benefits that workers received and, at the same time, shifted the burden of insuring workplace accidents from workers to employers. This shift in the burden of insuring is central to understanding the origins of workers' compensation.

The enactment of workers' compensation, like that of most other types of labor legislation, was a political compromise between employers and workers. Employers generally supported the concept of workers' compensation, as long as benefit levels did not replace more than two-thirds of the worker's normal wages. Further, as long as employers were able to pass the costs of higher post- 
accident compensation onto their workers in the form of lower wages (Fishback and Kantor 1994; see also Viscusi and Moore, 1990 and Gruber and Krueger, 1991), their opposition to the proposed law was diminished. Given that many workers paid for the relatively generous post-accident benefits that the law mandated, it would seem that they should have been politically indifferent to the legislation. But this reasoning assumes that the employer-provided insurance would have simply substituted for the worker's own insurance policy against accident risk. We find in this paper, however, that this assumption is mistaken -- workers faced binding constraints on their ability to purchase workplace accident insurance in the early 1900 s. Thus, risk-averse workers probably benefited from the passage of workers' compensation because they were now better insured against workplace accident risk than before.

Empirically determining whether workers could actually purchase their desired levels of accident insurance prior to the adoption of workers' compensation is difficult because accurately specifying an individual's preferences is of course difficult. ${ }^{2}$ We offer an alternative method by examining how households changed their saving and insurance purchases in response to the rise in post-accident compensation associated with the switch to workers' compensation. A theoretical model of insuring and saving behavior suggests that how saving responded to the switch to workers' compensation can be used as a signal of the market availability of accident insurance. If insurance purchases were unconstrained, we show that workers would not have used saving to insure against workplace accident risk and the switch to workers' compensation should have led to an increase in saving. If insurance were rationed, imposing binding constraints on the amounts of insurance that workers could buy, the worker's primary option was to use saving as a means of insuring against workplace accident risk. The switch to workers' compensation in this situation would then have led to a reduction in the household's precautionary saving.

An analysis of saving and insurance purchases by the households surveyed for the 1917-1919 
Bureau of Labor Statistics (BLS) Cost-of-Living study shows that saving was indeed lower in states where workers' compensation was in force. The result suggests that insurance companies were unable to effectively offer accident insurance to a wide range of workers. Evidence on the insurance market at the time suggests that accident insurance companies faced substantially greater information problems in selling individual accident insurance than in selling liability insurance to employers. Thus, by shifting the burden of insurance from workers to employers, workers' compensation benefited risk-averse workers who were rationed out of the insurance market, even if they paid for their more generous post-accident benefits in the form of lower wages. Moreover, employers may have been largely indifferent to the legislation if they could pass their increased accident costs onto their workers. Insurance companies stood to gain from the passage of workers' compensation because the law enabled them to expand their coverage of workplace accident risk.

The remainder of the paper is divided into four sections. In the next section we describe the nature of post-accident compensation prior to workers' compensation and outline the variety of ways that the working class could insure against workplace accident risk. In Section 3 we develop a theoretical model of insuring and saving behavior that indicates how the impact of workers' compensation on saving can be used as a signal of the market availability of accident insurance. In Section 4 an empirical analysis of saving and insurance purchases by the households surveyed for the 1917-1919 BLS Cost-of-Living study shows that saving fell when workers' compensation was introduced. The result implies that there were limits on the amounts of workplace accident insurance workers could purchase. In Section 5 we provide anecdotal and some quantitative evidence from the insurance industry that supports our empirical findings. The insurance industry faced substantial informational problems in providing personal accident insurance, but was much more effective at providing firm-level coverage. Finally, in the concluding section we discuss how our results offer a perspective on current proposals to modify the liability for workplace and product accidents. Our 
findings suggest that a movement back to first party insurance (i.e., the injured is responsible for his own insurance), as some scholars propose, may be fraught with its own set of complications.

\section{Accident Compensation Before and After Workers' Compensation}

De jure reparation by employers for job-related accidents before workers' compensation was determined according to the common law rules of negligence. Under the negligence liability system an employer was expected to exercise "due care" in protecting his employees against workplace hazards. ${ }^{3}$ The employer was legally obligated to hire "suitable and sufficient" co-workers; to establish and to enforce proper rules of conduct within the work environment; to provide a safe workplace; to furnish safe equipment; and to provide employees with warnings and suitable instructions in the face of dangerous working conditions. In order to collect accident compensation, an injured worker bore the burden of showing that his employer had failed to exercise due care in carrying out these duties and that the employer's negligence was the proximate cause of the injury. Even if an employer were found to be negligent, he could escape liability through three common law defenses: that the employee had assumed the risks associated with the employment (assumption of risk); that a co-worker (fellow servant) had caused the accident; or that the worker himself was negligent or had not exercised due care (contributory negligence). ${ }^{4}$

Proving the employer's negligence and overcoming the three defenses in a court of law was a costly and often formidable task. Pushing a suit through the court system often led to delays of two to five years between the date of the accident and a final court decision. In addition, there was a great deal of uncertainty about the results of the decision. As a result, the vast majority of workers sold their "rights of action" in out-of-court settlements. A study of accident compensation under the employers' liability system in Minnesota in 1909-1910 shows that 89 percent of fatal accident cases, 78 percent of permanent partial disability cases, and 99 percent of the temporary disabilities were 
settled without the courts (Minnesota, pp. 167-87).

Fishback and Kantor (1994) collected data from a variety of state-level studies on the operation of the employers' liability system. Among families of fatal accident victims, the percentages receiving no compensation at all ranged from 20.4 percent in a New York Department of Labor sample to as high as 60.9 percent among men killed in Illinois before 1911. Employers paid those families who received some positive award an average amount equal to 61 to 154 percent of the deceased worker's annual earnings. Almost none of the families received compensation that fully replaced the expected earnings of the deceased worker. When families receiving no compensation are included in the averages, the mean level of post-accident compensation for fatalities ranged from 38.3 percent of annual earnings for married men in Pennsylvania to 119.5 percent in Minnesota. ${ }^{5}$ Expecting relatively low benefits if their primary wage earners were killed on the job, families certainly had an incentive to plan for the possible financial loss.

Contemporary evidence suggests that working class families had several methods of insuring against workplace accidents prior to the introduction of workers' compensation. Families could always save against the possibility of an accident. However, saving was a relatively costly means of insurance. At an interest rate of 5 percent, for example, a family that sought to hold a year's income in reserve would have had to forego consumption of 95 percent of their income in the current year or wait several years to reach that goal. Families could also send children to work if the primary wageearner were injured or killed in an accident. Although advocates of child labor reform decried greedy parents' abuse of children, Modell (1979), Goldin (1981), Haines (1985), Keyssar (1986, pp. 158-60), and Rotella and Alter (1993) have found that sending children to work was an important means through which families survived hard times and accumulated savings at the turn of the century.

Families also bought life insurance. Industrial insurance accounted for 63.2 percent of the 36.5 million life insurance policies written in the U.S. in 1910 (Kip, 1953, p. 15). The industrial 
policies offered an average payout of $\$ 138$ (Kip, 1953, p. 18), which generally covered only the cost of a burial and thus was commonly referred to as "burial" insurance (Dryden, 1914, p. 384; Ackerman, 1926, pp. 5-12).

Families who sought to replace a worker's income if he died had three main options: old-line or whole-life insurance; fraternal life insurance; and accident insurance. With about $\$ 13.2$ billion worth of insurance in force in 1910 , the whole-life policy represented the dominant form of life insurance in the early 1900s (Kip, 1953, p. 12). Whole-life policies insured lives and incorporated the accumulation of dividends that could be borrowed against or surrendered.

The working class also insured through fraternal societies. These were mostly national organizations bound together by religious, occupational, ethnic, or fraternal ties. Most local societies belonged to a national parent organization that issued "certificates" of membership that entitled members' beneficiaries to death benefits and usually provided for a limited stream of payments in the event of disability (Nichols 1914; Insurance Research and Review Service 1938; Kip 1953). There were no standard death benefits and disability plans, so each worker's access to fraternal insurance varied depending on his religion, occupation, industry, or labor organization (for example, see U.S. Department of Commerce and Labor 1909).

The three types of life insurance above were not directly targeted at workplace accidents because they insured against all causes of death. Mortality statistics for the working-age population suggest that workplace accidents probably accounted for at most 2 percent of all deaths from 1915 to $1920 .^{6}$ Insurance companies therefore designed accident insurance that limited their liability to injury and death arising from "external, violent, and accidental means." Precisely defining an accident was an evolving enterprise as insurers and insureds relied on the courts to settle vast differences in interpretation (Cornelius 1920). Accident insurance was clearly written with an eye toward insuring occupational accident risk, as each industry and occupational class was categorized according to its 
level of danger (Aetna 1919). Evidence offered by Faulkner (1940, p. 27) suggests that occupational accidents accounted for approximately 63.3 percent of all accidental deaths in 1913 , although the percentage had fallen to 28.3 percent by 1938 because of advancements in safety programs and devices. ${ }^{7}$ Payment of benefits, moreover, followed strict guidelines: benefits were paid provided that the accident was not

incurred while the insured is not unnecessarily exposing himself to 'obvious danger,' and while he is not engaged in an occupation more hazardous than that in which he has elected to be classified and insured; or if more hazardously occupied at the time of injury, then recovery can be had only to the extent to which the premium paid would have purchased insurance in the more hazardous class (Cyclopedia of Insurance, 1913, p. 3).

Although accident insurance represented the most direct way for workers to insure against occupational accident risk, the personal accident insurance business was relatively small. Only $\$ 18.8$ million in accident premiums were collected by commercial insurance companies in 1911, compared with $\$ 564.7$ million in standard life premiums and $\$ 750.9$ million in industrial life premiums (Cyclopedia of Insurance, 1913, pp. 4, 154-5, 180-1).

Various state and federal government surveys around the turn of the century provide evidence on the extent to which workers insured before workers' compensation laws were introduced. Robert Whaples and David Buffum (1991, p. 102) found that 16 percent of the 5,020 Michigan furniture workers in an 1890 survey purchased some form of life insurance, with an average value of $\$ 1539$. Forty percent of the workers in their sample claimed accident/sickness insurance through membership in a benefit society. In their logit analysis Buffum and Whaples found that workers who had to "take care on the job to avoid injury" were more likely to have insurance. ${ }^{8}$

Surveys of Kansas nonagricultural workers from 1884 through 1887 show that 26 percent 
belonged to benefit societies, 36 percent had fire or life insurance (although 46 percent owned homes, some of which were probably fire-insured), while 5.5 percent had bought some form of accident insurance. ${ }^{9}$ In an 1890 survey of Maine workers (see Ransom and Sutch, 1990), 22.8 percent claimed to have had life insurance, while 32.6 percent were members of a benefit society. There was a definite overlap between the groups, however, as 83 percent of the people with life insurance were also members of benefit societies and 58 percent of the benefit society members held life insurance.

Mary Conyngton (1917) surveyed families of workers killed in workplace accidents in 1915 to compare their living standards under negligence liability and workers' compensation. In Pennsylvania under negligence liability, 82.1 percent of the families received payments from some form of insurance, compared with 63 percent in the workers' compensation states of Ohio and Connecticut. Moreover, prior to the adoption of workers' compensation, the Minnesota Bureau of Labor (19091910) found that 46.3 percent of the families of fatal accident victims collected insurance that replaced an average of 1.4 times the deceased's annual earnings.

The most comprehensive information on household purchases of insurance comes from the Bureau of Labor Statistics' 1917-1919 Cost-of-Living Survey, which is the evidence analyzed later in the paper. Table 1 shows the percentage of the sample that held each type of insurance policy. Some form of life insurance was reported by 85.2 percent of the sample, although, as described below, the survey undersampled the relatively poor working class, factory operatives and laborers. When burial insurance policies are excluded, about half of the workers surveyed had life insurance. Whole-life (old-line) insurance and fraternal insurance were each carried by about a quarter of the workers surveyed, but only 10 percent chose accident insurance coverage.

The workers' life insurance coverage clearly did not replace the full loss of the stream of income when they died. The present value of the remaining stream of income for a worker between 30 and 40 years of age with a discount rate of 10 percent ranged between 8 and 10 times his annual 
income. The typical household seems to have bought only enough insurance to replace about one year's income. ${ }^{10}$

Expecting rather meager payments from their employers if injured or killed on the job, many workers and their families predictably sought private means of insuring. The adoption of workers' compensation laws, however, dramatically changed the nature of post-accident compensation and, presumably, the incentive to privately insure. The laws, which were enacted at the state-level beginning in 1911, established that all workers were to be compensated for injuries arising "out of and in the course of employment." 11 The move to workers' compensation translated into two important changes for working class families. First, they were much more likely to receive accident benefits. Conyngton's (1917, p. 109) study of the compensation paid to families of fatally injured workers in the workers' compensation states of Ohio and Connecticut in 1915 showed that only 2.9 and 9.4 percent, respectively, received no death benefits under workers' compensation. In the uncompensated cases there may have been uncertainty as to whether the death was job-related or the workers may have been intoxicated on the job. Second, the amount paid to each family receiving compensation rose sharply. Recall that under negligence liability a family of a fatal accident victim receiving some amount of compensation typically received 0.6 to 1.5 times the deceased's annual income. This figure jumped under workers' compensation to a stream of benefits with a present value (discounted at 10 percent) of roughly 2.3 times annual income.

The generosity of the workers' compensation laws varied substantially across states. Table 2 shows the expected present value of the stream of accident benefits on January 1, 1918 for a worker receiving $\$ 27.2$ per week, the mean in the sample we later analyze. As discussed in Appendix A, the expected benefit is the weighted sum of the present value of the stream of benefits the worker or his family would have received for accidents causing death, permanent total disability, permanent partial disability, and temporary disability. The probability of each type of accident occurring is used as the 
weight. The expected benefits calculations confirm the sharp jump in benefits when moving from negligence liability to workers' compensation. In the negligence liability states in 1918 , expected benefits ranged from $\$ 2.11$ in Arkansas and Missouri to $\$ 6.33$ in Tennessee and North Dakota. Expected benefits in the workers' compensation states ranged from $\$ 8.29$ in Colorado to $\$ 23.76$ in Nevada. Even with the sharp rise in post-accident payments, however, workers' families were not fully compensated for the loss of their primary bread-winners. For example, the present value of fatal accident benefits under workers' compensation typically replaced between 2 and 4.5 years of income, while the present value of the lost stream of earnings would have been 8 to 10 times annual income.

\section{A Model of Insurance Consumption and Saving Behavior}

How did the rise in post-accident benefits associated with workers' compensation influence a household's decision to save for and insure against a workplace accident? The answer depends on whether the worker's access to insurance purchases was rationed or not. If the worker's access to insurance were unrationed, such that he could buy his desired amount of insurance at a price below the opportunity cost of saving, he would have bought less insurance and saved more when postaccident benefits increased. If access were rationed such that the worker faced a binding constraint on the amount of insurance he could purchase, increases in post-accident benefits would have led him to reduce his saving. Increases in post-accident benefits would have affected accident insurance purchases only if the worker's new optimal level of insurance purchases fell below the original binding constraint.

These effects can be shown by deriving the household's demand for saving and insurance in a two-period, expected-utility framework, which captures the essential elements of the household's decision. Assume that the household maximizes its expected utility of consumption over two periods. 
In the first period total household income includes the earnings of the household head, $y$, and other household income, denoted $n$, which might include other family members' earnings and nonwage income, such as rent from boarders. At the beginning of the second period, the household head might have a workplace accident with probability $q(0 \leq q \leq 1)$. If the primary wage earner has no accident, then the family again receives $y$ and $n$ in period 2 . If the head of the household is killed on the job, the family still earns $n$ from other family members plus a post-accident payment of $C$. The family can adjust its income stream across time periods by saving an amount $s$ in period 1 , which earns an interest rate $r$. The family can also insure against the income loss from an accident by paying a premium $p$ that insures a payment of $I$ if the household head is killed. We have parameterized the model to treat the consumption goods as the numeraire.

The household's budget constraints can be written as follows:

$$
\begin{array}{ll}
n+y=x_{1}+p I+s & \text { in period } 1 \\
n+y+(1+r) s=x_{2 n} & \text { in period } 2 \text { if no accident occurs, and } \\
n+(1+r) s+C+I=x_{2 a} & \text { in period } 2 \text { if an accident occurs. }
\end{array}
$$

Consumption in the first period is denoted $x_{1}, x_{2 n}$ is consumption in the second period with no accident, and $x_{2 a}$ is consumption in the second period with an accident. The household's expected utility over the two periods can be written as

$$
Z\left(x_{1}, x_{2 n}, x_{2 n}\right)=U\left(x_{1}\right)+(1-q) V\left(x_{2 n}\right)+q W\left(x_{2 n}\right) .
$$

The use of different non-accident utility functions $(U$ and $V$ ) for the two time periods implicitly reflects the household's discount rate. Different second-period utility functions for the nonaccident $(V)$ and accident states $(W)$ reflects lower utility for the same income when the family loses a loved one to an accident (see Viscusi and Evans, 1992). All three utility functions are assumed to rise at a diminishing rate with increasing consumption (i.e., $U^{\prime}>0, V^{\prime}>0, W^{\prime}>0, U^{\prime \prime}<0, V^{\prime \prime}<0$, and $\left.W^{\prime \prime}<0\right)$. 
After solving the budget constraints for $x_{1}, x_{2 n}$, and $x_{22}$ and substituting them into the utility function, we can derive the comparative statics in the case when insurance is not rationed. In this unconstrained setting, the household chooses a saving level $s$ and insurance purchases $I$ to maximize the following objective function:

$Z(s, I)=U(n+y-p I-s)+(1-q) V(n+y+(1+r) s)+q W(n+C+I+(1+r) s)$.

The first order conditions for a maximum are

$$
\begin{aligned}
& Z_{1}=-U^{\prime}\left(x_{1}\right)+(1+r)(1-q) V^{\prime}\left(x_{2 n}\right)+q(1+r) W^{\prime}\left(x_{2 a}\right)=0 \\
& Z_{1}=-p U^{\prime}\left(x_{1}\right)+q W^{\prime}\left(x_{2 a}\right)=0
\end{aligned}
$$

where $Z_{1}$ and $Z_{1}$ are the first derivatives of $Z$ with respect to saving and insurance, respectively. The first order conditions imply that the household chooses saving and insurance levels such that the ratio of the marginal utility in the first period to the expected marginal utility in the second period $\left[U^{\prime}\left(x_{1}\right) /\left((1-q) V^{\prime}\left(x_{2 n}\right)+q W^{\prime}\left(x_{2 a}\right)\right)\right]$ is equal to $(1+r)$ and the ratio of the marginal utility in the first period to the marginal utility if an accident occurs in the second period $\left[U^{\prime}\left(x_{1}\right) / W^{\prime}\left(x_{2 a}\right)\right]$ is equal to the ratio of the probability of an accident to the insurance premium $[q / p]$.

Denote the demand functions for insurance and saving derived from these first order conditions as $s^{*}=s^{*}(y, n, r, p, q, C)$ and $r=r^{*}(y, n, r, p, q, C)$, respectively. The saving and insurance decisions become functions of the income of the household head $(y)$, the nonwage income and income of other family members $(n)$, the interest rate on saving $(r)$, the probability of a workplace accident $(q)$, the premium paid for accident insurance $(p)$, and post-accident payments $(C)$. Of course, these decisions will also be influenced by differences in household preferences (particularly rates of time preference), which might be based on the age of the household head, the number and ages of children in the family, the skill levels of the workers in the household, or their union statuses.

The comparative statics of the unconstrained model are derived in Appendix B. They show that increases in post-accident payments (C) lead to reductions in insurance purchases and increases in 
saving as long as the insurance premium $(p)$ is lower than the opportunity cost of saving $(1 /(1+r))$ for insurance purposes. If insurance were actuarially fair, then $p$ would be substantially below $1 /(1+r)$. Since the market interest rate almost never exceeded $0.1,1 /(1+r)$ was no lower than 0.9 . Meanwhile, the probability of a fatal workplace accident $(q)$ was probably no higher than 0.005 (the probability of any type of accident was no greater than 0.2$)$. Thus, for $p$ to exceed $1 /(1+r)$ the insurance company had to charge an enormous load factor on insurance or not sell insurance at all (implying an infinite price of insurance). ${ }^{12}$ In fact, if $p$ exceeded $1 /(1+r)$, the worker could not achieve an optimum maximum because the first-order conditions would never hold.

The comparative statics change markedly when insurance purchases are assumed to be rationed. Insurance companies, in response to problems with adverse selection, often establish maximums for the amount of insurance people can buy and in some cases sell no insurance at all. If this constraint is binding, the worker faces a maximization problem with the extra constraint that insurance purchases $I$ equal the maximum $M$. The maximization problem then becomes a Lagrangian with an objective function

$X(s, I, u)=U(n+y-p I-s)+(1-q) V(n+y+(1+r) s)+q W(n+C+I+(1+r) s)+u(M-I)$.

After deriving the first-order conditions (shown in Appendix B), we can derive the new demand functions for insurance and saving derived, which are now $s^{c}=s^{c}(y, n, r, p, q, C, M)$ and $r=$ $\Gamma(y, n, r, p, q, C, M)$. The comparative statics (derived in Appendix B) reveal that increases in postaccident benefits $(C)$ would cause workers to save less. As long as the insurance constraint remained binding, insurance purchases would remain unchanged. However, insurance purchases might fall if the workers' new optimum was below the accident insurance constraint.

The intuition underlying the differences in the saving response in the unconstrained and 
rationed cases is relatively simple. If insurance were not rationed and priced near actuarial fairness, the worker would have found it much less costly to buy accident insurance than to use saving for insurance purchases. An increase in post-accident benefits would have allowed him to purchase smaller amounts of insurance, thus freeing funds for more saving and consumption. If accident insurance, on the other hand, were constrained at the maximum, then saving became a more reasonable means of insuring against the risk of an accident, and increases in post-accident compensation would have led to reductions in saving.

The remaining comparative statics of the model show that the accident rate $(q)$ and the price of insurance $(p)$ have ambiguous effects on saving and insurance consumption. It seems reasonable to assume that insurance is not a Giffen good and therefore the household would purchase less insurance when the premiums rise. It is difficult to empirically determine the effects of accident rates and insurance premiums on insurance consumption because premiums are often based on the probability of an accident. When $p$ and $q$ move together, the impact of the accident rate on saving and insurance purchases is also theoretically indeterminate. Changes in the primary wage earner's income lead to ambiguous effects on saving and insurance consumption, although some historical studies have found that these activities are normal goods (Haines 1985; Whaples and Buffum 1991). Similarly, changes in other family members' income and other income sources have ambiguous effects on both insurance purchases and saving. Finally, the model predicts that increases in interest rates have ambiguous effects on both saving and insuring.

\section{An Empirical Analysis of Saving and Insuring}

The household's ability to purchase its desired amount of insurance is signalled by the effect of post-accident compensation on saving. We examine this issue using cross-sectional data on families' financial decisions in both workers' compensation states and negligence liability states. 
Between late 1917 and early 1919 the U.S. Bureau of Labor Statistics conducted an intricate analysis of the consumption patterns of working class families in industrial centers of the United States. The study ultimately led to the construction of the consumer price index (Cost of Living in the United States. 1917-1919). Agents interviewed 12,817 families of wage earners or salaried workers in 99 cities in $\mathbf{4 2}$ states. Although the BLS believed that the survey families fairly represented the urban population at the time, the investigation was limited in a number of important ways. The interviewers surveyed only households of wage and salary earners where both spouses and one or more children were present. The salaried workers were not to earn more than $\$ 2,000$ a year and the families had to reside in the same community for a year prior to the survey. Further, the BLS excluded families with more than three boarders, "slum" families, charity families, and non-English speaking families who had been in the U.S. less than five years. As a result, craft workers and other high wage workers were oversampled relative to factory operatives and laborers. Also, it is not clear how random the survey was because there are large numbers of workers from the same industries close together in the sample. This bunching may imply that interviewers simply picked a specific neighborhood in a city. When we analyzed the sample, however, we found that the bunching of industries was strongest in one-industry towns like the copper town of Bisbee, Arizona, where a random sample anywhere in town would have led to large numbers of workers in the same industry.

We imposed some additional limits on the sample, restricting it to laborers, operatives, and craft workers for several reasons. First, domestic service workers and farm workers were excluded because workers' compensation laws usually exempted these occupations from coverage. Second, we eliminated managers, professionals and semi-professionals, salesmen, and clerical workers because our measures of accident risk largely pertains to the workers directly involved in the defining activities of that industry. ${ }^{13}$ The exclusions reduce measurement error because the managerial, sales, and clerical workers were typically not exposed to the same accident risk as manufacturing workers. 
Third, men working in the maritime industry were eliminated from the sample because the nature of their post-accident compensation was in a state of flux at the time of the survey. ${ }^{14}$ Fourth, railroad workers were eliminated because of inadequate information on their post-accident compensation. Railroad workers typically fared better than nonrailroad workers under negligence liability because the employers could not invoke the fellow-servant and contributory negligence defenses after 1908 . However, we are uncertain how they fared relative to nonrailroad workers under workers' compensation. Fifth, government workers were eliminated because the status of post-accident compensation for these workers was ill-defined in many states. ${ }^{15}$ After all of these restrictions to the original sample, we were left with a total of 7,475 observations.

The Cost-of-Living Survey contains information on household purchases of accident and life insurance and household saving. Saving is defined as the household's total income minus its total expenditures. The BLS survey asked the family how many people in the household had accident insurance. In the overall sample 89.1 percent responded that no one had accident insurance, 10.1 percent responded that at least one person had accident insurance, and only 0.8 percent responded that more than one person had insurance. Presumably, the predominance of households with just one accident insurance policy were insuring the household head, the primary wage-earner. We used the information to create a dummy variable with value one if the household held one or more accident insurance policies.

The BLS also asked about the number of household members with five different types of life insurance -- old-line (whole-life), fraternal, industrial, establishment, and other types. Because life insurance coverage covered so many more people within the household than accident insurance, the life insurance variable by necessity focuses on the purchases of life insurance for all members of the household. We used the information to create a dummy variable valued at one if the household claimed at least one life insurance policy, and zero otherwise. Given the zero-one nature of the 
variables we estimated probit equations.

The equations to be estimated include a number of variables designed to capture differences in demand across households. Variables specific to the household head include his age, age squared, annual earnings, dummy variables controlling for his occupational skill level, whether he contributed to a labor organization, an accident risk measure, and the expected value of post-accident compensation. Other demand variables pertained more specifically to the household's financial status. The regressions include the wife's annual earnings, the children's earnings, income from boarding and lodging, net income from rent and interest, and the number of children between 0 and 4 years old, 5 and 9,10 and 14, and older than 14. To capture differences in the cost of living, we included an index of the average cost-of-living in urban areas in each state for the period 1919-1921. We have also included regional dummy variables to capture geographic differences in interest rates caused by differences in banking regulations and differences in insurance premiums caused by state-specific regulations or varying costs of selling and monitoring policies across the country.

To measure the workplace accident risk that the worker faced, we matched each worker's industry with the premium paid per $\$ 100$ on the payroll that employers in that industry were required to pay into the Ohio State Workmen's Compensation Fund in 1923. Note that this premium is not the one that workers paid for personal life or accident insurance. We chose the Ohio information because Ohio had a wider range of industries than any other state where premiums were available. The premiums that employers paid should be correlated with fatal and nonfatal accident risk in the workplace because the Ohio Industrial Commission sought to price the insurance so that industries paid for the accident costs they generated. To some extent, this accident risk measure should be correlated with the accident insurance premium that a worker would have paid for private accident insurance, which was priced according to his particular industry and occupation.

As shown in Table 2, post-accident compensation varied widely between workers' 
compensation and negligence liability states and also across workers' compensation states. Since a simple workers' compensation dummy cannot adequately capture the variation across workers' compensation states, we have calculated the present value of the worker's expected accident benefits using his wage and the statutes of the state where he resided following the procedure that gave the estimates in Table 2. First, we calculated the present value of the stream of benefits a worker or his family would have received if the worker were killed, suffered a permanent total disability, a permanent partial disability, and a temporary five-week disability. We then converted these benefit estimates into an expected benefit measure by weighting each of the four types of accident benefits by the probability of each type of accident occurring and then summing the four expected compensation estimates. Appendix A offers more details on the calculations. The expected benefits measure the monetary value that a risk-neutral worker would place on his expected accident compensation.

Individual differences in the premiums for accident and life insurance might be proxied in two ways. The Ohio accident risk variable should be associated with higher accident insurance premiums since companies charged workers higher rates if they were engaged in more dangerous work (Aetna 1919). The regional dummy variables may also capture some of the geographical differences that affected the price of insurance. ${ }^{16}$

Results from the probit estimations of life and accident insurance coverage and ordinary least squares estimation of the saving equation are presented in Table 3. Life insurance appears to be largely unaffected by differences in expected benefits. The coefficient of the expected benefits variable is negative, but it is not statistically significant. Evaluated at the mean probability of life insurance, a one-standard-deviation increase of expected benefits of $\$ 5.9$ would have lowered the probability of purchasing life insurance by only 0.8 percentage points from 86 percent to 85.2 percent. The small effect on life insurance coverage might have been associated with the fact that life insurance was not really targeted at workplace accident risk. Recall that workplace accidents 
accounted for no more than 2 percent of the fatalities for the working-age population during this time period. Thus, workers may not have changed their life insurance coverage much in response to changes in post-accident benefits because they were largely insuring against fatality risks not associated with the workplace. ${ }^{17}$

Expected benefits had more influence on the probability of purchasing accident insurance, suggesting that higher benefits might have lowered the desired level of accident insurance below the constraints imposed by insurers for at least some workers. Where expected benefits were onestandard-deviation higher starting from the mean, the probability of purchasing accident insurance was a statistically significant 2.1 percentage points lower.

The results for saving are consistent with the view that workers faced binding constraints in the insurance market. The theoretical models suggest that if workers faced binding constraints on their insurance purchases, workers would have reduced their saving as post-accident insurance increased. The coefficient in the saving regression in Table 3 indicates that each dollar increase in expected benefits was associated with a reduction in saving of $\$ 1.56$, which is statistically different from zero. ${ }^{18}$ If a worker had moved from Virginia to Maryland, for example, his expected benefits would have risen by approximately $\$ 10$, all else equal. Such an increase would have allowed him to reduce his saving by about $\$ 15.60$. The size of the effect gives an indication of the costliness of using saving for insurance purchases, as workers were able to reduce their precautionary saving substantially more than the expected monetary value of the change in post-accident compensation. ${ }^{19}$

There may be worries that the regional dummy variables are capturing some of the impact of workers' compensation, so we have estimated the equation without the regional dummies. The coefficient is slightly smaller at -1.207 and remains statistically significant. It should be noted, however, that F-tests reject the hypothesis that the coefficients of the regional dummies are simultaneously zero. 
There may be worries that the estimates of post-accident compensation are capturing alternative influences. For example, the states without workers' compensation in 1918 tended to be southern states, where saving might have been lower. Further, there may be questions about measurement error in the non-workers' compensation states because we could not rely on explicit laws to estimate the expected accident benefits in such states. Such concerns are unfounded. The saving regression includes income and regional dummies that should control for this effect. Further, we estimated the equation on a sample that eliminated the non-workers' compensation states. The expected benefits coefficient was actually somewhat larger at -2.51 with a $t$-statistic of -4.53 .

Another more serious worry is that the survey was taken during World War I, which was a period of substantial upheaval. The government became heavily involved in labor markets and the economy experienced substantial demand and supply shocks that were likely to be unevenly distributed geographically. The saving results potentially could be spurious if these shocks were correlated in some way with the generosity of workers' compensation statutes across states. We have tested for this possibility by estimating the saving regression on an alternative sample of households from the BLS survey that would be generally unaffected by the expected benefits under workers compensation. In this sample we included professional and clerical workers who did not face the risks that operatives, workers, and craftsmen faced, domestic service workers who were not covered by workers compensation, federal government workers who were covered under federal workers' compensation law, and railroad workers who were involved in interstate commerce and were covered under an entirely different set of liability rules. For each worker in this alternative sample we calculated the expected benefits as if he were covered under his state's workers' compensation law and faced the same accident risk as that of manufacturing operatives and skilled workers in his particular industry. Given that these households' decisions were not in actuality affected by the generosity of their states' workers' compensation programs, we should expect to find a small and 
statistically insignificant effect of expected benefits. That is exactly what we do find. The expected benefits coefficient when regional dummies are included is small at -0.415 , roughly one-fourth the size of the coefficient in Table 3, and we cannot reject the hypothesis that the coefficient is zero (tstatistic of -0.475 ). In an equation with the regional dummies excluded, the coefficient is 0.43 and again is statistically insignificant (t-statistic of 0.71 ).

While the results in Table 3 suggest that insurance was rationed, the bias of omitted variables might affect the coefficient of post-accident benefits in the saving equation in Table 3 . Theoretically, when insurance is rationed, the accident insurance maximum $(M)$ belongs in the saving equation, but it is absent from the empirical saving equation in Table 3. We faced a major problem in determining the insurance maximums. As an attempt to control for the insurance maximums in the regressions, we reestimated the saving equation using the predictions from the insurance probits as a proxy for the rationing of life and accident insurance. ${ }^{20}$ The coefficients of the post-accident benefits variable in the reestimations of the saving equations are similar to the ones reported in Table 3. When regional dummies are included in the saving equation the coefficient was -1.973 (t-statistic of -2.84$)$. When the specification excluded regional dummies the coefficient was -1.21 ( $\mathrm{t}$-statistic of -1.21 ). The remaining coefficients (and their standard errors) in these saving regressions are also very close to those reported in Table 3.

Most of the other variables in Table 3 tended to affect saving and insurance as expected. The age variables indicate that saving and insurance purchases increased at a diminishing rate with age, but the coefficients are not statistically significant. Higher earnings from the husband were associated with more saving and insurance coverage, while the earnings of other household members had a positive effects on saving, but varied effects on accident insurance purchases. Households also saved less as they had more older children. For example, an additional child between 0 and 4 lowered saving by $\$ 17$, but one more child older than 15 years reduced saving by $\$ 37$. This result may be 
driven by the fact that saving is measured as a residual (household income minus expenditures), and older children may have consumed more in terms of food and clothing. Alternatively, the result might be interpreted as evidence that families used children as substitutes for precautionary saving. Having children in the household who could be sent to work in case of financial hardship meant that families did not have to rely so heavily on their savings accounts as a means of insurance.

\section{Why Was Accident Insurance Limited?}

The negative relationship between saving and post-accident benefits implies that accident insurance was either unavailable to many workers or rationed. Why did insurance companies not offer more accident insurance to individual workers?

The answer seems to lie in the standard asymmetric information problem that all insurers face. Insurers of employers' liability had solved the information problems to a far greater extent than accident insurers by World War I. The National Bureau of Casualty and Surety Underwriters had collected information on the loss, premium, and payroll experiences of stock companies insuring employers and was publishing premium rates for employers in various industries, occupations, and industrial processes. They also published information on adjusting the national rates for differences in liability rules and experiences across states. In addition, a number of companies adjusted negligence liability premiums for individual employers based on inspections of safety precautions or a loose firmspecific experience rating. In contrast, Kulp (1928, p. 575) found that premiums for individual accident insurance sold to workers were made "by the individual companies, and largely by rule of thumb ... only recently has the Bureau of Personal and Accident and Health Underwriters begun the collection of experience in a form usable for rate-making, but there is no certainty that any such use will be made of it."

Insurers of individual workers faced additional problems because they had to determine the 
accident proneness of the worker. Workers had partial control over the accident environment based on their own care or their own ability to prevent accidents. With little information on the accident proneness of the individual, the insurance companies had to base insurance premiums on occupational averages. Such pricing would have led to adverse selection problems, as accident-prone workers would have purchased the insurance and more careful workers would not. Insurance companies could expect no help from employers in identifying accident-prone workers because negligence liability rules allowed employers to avoid compensating careless workers' accidents. Thus, employers had less incentive to fire irresponsible workers or to impose restrictions on their behavior.

The standard means of reducing problems of adverse selection is to limit the amount of insurance the worker could buy or to establish pricing policies designed to discourage more accidentprone individuals. Accident insurers followed both practices. The Aetna Life Insurance Company (1919, pp. 96) imposed limits on the risk they would insure, imposing death benefit maximums as low as $\$ 250$ on coal miners, who faced very dangerous working conditions. Further, accident insurance was noted for its high load factors. Even with the high loads, a number of companies writing accident insurance failed over the period 1917 to 1926 , while the surviving stock companies suffered a slight underwriting loss (Kulp, 1928, p. 576). The end result was that many workers could not purchase their desired levels of accident insurance, and some may have been shut out of the market altogether.

The problems in selling individual accident insurance may explain why insurance companies favored the general idea of workers' compensation, as long as state governments did not establish their own insurance funds (see, for instance, Aetna 1914, p. 16). After all, their the amount of insurance they could profitably underwrite was likely to increase. The rise in post-accident payments from employers to workers under workers' compensation meant that employers would purchase substantially larger amounts of insurance than they did under negligence liability. In fact, premiums 
collected by commercial insurance companies for workers' compensation insurance rose from zero in 1911 to $\$ 114$ million in 1920 , despite the presence of compulsory state funds in 6 states and competing state funds in 11 more. The $\$ 114$ million rise more than offset a $\$ 41.5$ million shortfall in employers' liability premiums between the actual level of $\$ 86$ million in 1920 and a predicted level of $\$ 129.5$ million based on the annual growth rate from 1905 to 1911 , the years prior to the introduction of workers' compensation laws. ${ }^{21}$ Workers' compensation legislation clearly expanded the effective opportunities for writing insurance.

Workers' compensation diminished the insurer's adverse selection problem of providing coverage for individual workers in two ways. First, under workers' compensation the employer insured the entire payroll in any risk class, limiting problems with adverse selection in that risk class. Second, given that the behavior of all the employer's workers determined his insurance premiums, not just the ones who exercised care on the job, employers had incentives to police the behavior of more careless and accident-prone workers, by either firing them and removing them from the risk pool or imposing limits on their behavior. Problems with adverse selection, however, were not eliminated entirely, as experience rating techniques were not perfect. Moreover, there still existed some adverse selection problem at the employer level because a number of states allowed employers to self-insure.

\section{Concluding Remarks}

Our finding that workers were unable to purchase as much private accident insurance as they demanded suggests that the introduction of workers' compensation might have provided very clear benefits to workers and insurers. Employers, on the other hand, were probably no worse off, even though the insurance burden was placed directly on them. Insurance companies were able to expand their coverage of workplace accidents because they could more effectively limit moral hazard and adverse selection problems when insuring employers, as opposed to individual workers. Risk-averse 
workers, even if they anticipated a full wage offset, stood to gain from workers' compensation because their access to individual accident insurance was limited and saving was a costly means of insuring against accident risk. In fact, limitations on workers' ability to insure may still exist today. Viscusi $(1991$, p. 82) shows that workers have been willing to accept wage declines that more than pay for the increased workers' compensation benefits that they receive. Finally, employers might not have been averse to accepting more of the burden of insuring accidents, as long as they could offset the large increase in post-accident compensation by lowering wages (see Fishback and Kantor, 1994). In fact, employers were major proponents of the switch to workers' compensation in many states (Lubove 1967; Weinstein 1967).22

The reassignment of liability from negligence liability to a form of strict liability under workers' compensation appears to have lowered the costs of insuring workplace accidents. The origins of workers' compensation do not necessarily imply, however, that a form of strict liability would be preferred to negligence liability in all settings. In the case of product liability, Priest (1987) argues that insurers would be more effective at insuring consumers than producers against product accident risk. The distinction between workers' compensation and product liability stems from the differences in the employer-worker and producer-consumer relationships. Employers can choose their own workers and limit their behavior in ways that lower the firm's costs of insuring against accident risks. On the other hand, producers have little control over who purchases their products and often no control over its use. Under a strict liability setting, insuring producers is more problematic than insuring employers because producers lack control over adverse selection and moral hazard in the use of the product. As we have shown in this paper, however, returning to negligence liability and firstparty insurance may be associated with its own set of difficulties. The feasibility of moving back to a form of negligence liability as a solution to the current insurance crises in product liability and workers' compensation depends on how well individual workers or the consumers of dangerous 
products will be able to privately insure against accident risk. 


\section{FOOTNOTES}

1. Placing a relatively larger burden of the financial losses associated with industrial accidents onto workers could be implemented in a number of ways: by lowering the maximum benefit payable; reducing the percentage of the worker's wage that is replaced during a disability; extending waiting periods; or restricting the types of injuries covered under workers' compensation.

2. For one attempt at measuring utility under different health statuses, see Viscusi and Evans (1992).

3. Landes and Posner (1987, pp. 85-87), citing Justice Hand's formula, claim that due care meant that the employer prevented accidents when his costs of prevention were lower than the expected costs of the accidents (i.e., losses to the accident victim times the probability of the accident).

4. See Clark (1908), Weiss (1935), and Epstein (1982) for lucid discussions of the employers' liability system.

5. These figures, we should note, are gross compensation and ignore the legal expenses that the victim's family often paid. In the 1910 study from Minnesota, legal expenses consumed, on average, 11.9 percent of the total compensation paid to the families of fatal accident victims. Further analysis shows that only 9 of the 54 families ( 16.7 percent) paid any legal fees, but they paid an average of 25 percent of their benefits to lawyers. At the higher end of the scale, in 151 accident cases investigated by the New York Department of Labor prior to 1910, legal costs amounted to 22.7 percent of the gross receipts from employers (including 97 cases settled directly between the parties) (Eastman, 1910, p. 289).

6. This statistic was derived from the U.S. Bureau of the Census, Mortality Statistics (1915, pp. $444-445 ; 1916$, p. $294 ; 1917$, p. $320 ; 1918$, p. 2961919 , p. $288 ; 1920$, p. 310). Because the 
Census did not report which deaths were caused by workplace accidents, we assumed that all accidental deaths from "absorption of deleterious gases," "traumatism by cutting or piercing instruments," "traumatism in mines and quarries," "traumatism by machines," and "railroad accidents and injuries" were work-related. Moreover, because railroad deaths also included passengers, we deflated the Mortality Statistics figure by the percentage of passenger deaths as reported by the Interstate Commerce Commission (these data are reported in U.S. Bureau of the Census 1975, p. 740). Although our measure of job-related deaths is very crude, it does suggest that relatively few people died as the result of a workplace accident.

7. Faulkner (1940, p. 27) reports that the rate of fatal occupational accidents was 45.7 per 100,000 population in 1913 and had fallen to 20.4 by 1938 . The death rate from all accidents was 72.2 per 100,000 population in 1938 , but Faulkner did not report the same statistic for 1913. Thus, in estimating that 63.3 percent of all fatal accidents occurred on the job, we have assumed that the death rate from all accidents was the same in 1913 as it was in 1938. This assumption seems reasonable given that the overall accidental death rate per 100,000 was 69.6 in 1922 .

8. Unfortunately, Whaples and Buffum provided no estimates of the amount of insurance coverage (even though these data were available), only probability estimates on whether the workers were insured or not.

9. See Ransom and Sutch (1989). The Kansas sample is skewed toward skilled workers and workers in cities far more than the actual distribution of Kansas workers, as reported in the Census' occupational statistics.

10. This estimate is based on answers to the BLS's questions about the value of insurance. We do not try to use the BLS estimates of the value of insurance further because there is a substantial problem with measurement error in the data. It was not clear whether the value of 
the insurance meant the benefit to be paid on death or the current cash value of the policy. Further, in the case of accident insurance, the presence of disability benefits makes the evaluation of the policy far more complicated. The confusion about the values of policies shows up in the large number of households that offered inconsistent answers to the different questions about insurance. Of the 6682 households that claimed to have life insurance policies, 1493 households reported a value of zero for their life insurance. Of the 780 households with accident insurance policies, 521 reported a zero value for their policies. We therefore focus on the question of whether people had insurance or not.

11. In most states, however, agriculture, domestic service, and casual labor were excluded from the compensation laws. Sometimes, specific industries were excluded. For example, Maine excluded logging, Maryland exempted country blacksmiths, and Texas excluded cotton ginning. For a more comprehensive summary of the exemptions across the United States, see U.S. Bureau of Labor Statistics (1918, p. 58).

12. Fishback (1992, p. 87) shows that the fatal accident rate in coal mining, probably the most dangerous occupation near the turn of the century, was about 0.002 . Fishback and Kantor (1994) found that the probability of temporary disability among sawmill workers (another dangerous profession) was 0.22 , which was higher than that for coal miners. Evidence presented by Davis $(1965$, pp. $360-1,384)$ indicates that 5 percent is a reasonable estimate of the interest rate on savings for the period under consideration.

13. We thank Martha Olney for making Claudia Goldin's occupation codes for these data available to us. Goldin matched the listed occupation in the Cost-of-Living Survey with the occupation codes developed for the 1940 Census Public Use Sample. In restricting the sample we eliminated professional and semi-professional workers (codes under 98), farmers and farm managers (98-99), proprietors, managers, and officials (100-156), clerical and kindred 
workers (200-266), salespeople (270-298), domestic service workers (500-520), protective service workers (600-614), service workers (700-798), farm laborers and foremen (844-888), and nonclassifiable occupations (998-999).

14. Originally, most maritime states with workers' compensation laws claimed jurisdiction over maritime industries, but the Supreme Court (Southern Pacific Co.v. Jensen, 244 U.S. 205) claimed that U.S. admiralty and maritime law made state compensation laws inapplicable to maritime injuries. On 6 October 1917, Congress enacted the Johnson amendment which allowed state workers' compensation laws to include maritime industries, but the law was declared unconstitutional by the Supreme Court in Knickerbocker Ice Co. v. Stewart (40 Sup. Ct. Rep. 438, 485). For a discussion of these legal events, see French (1920).

15. For example, Arizona, Delaware, and Texas did not include public employment under workers' compensation; New Hampshire and New Mexico did not mention public employees in the compensation act; lowa exempted firemen and policemen; Kentucky, Maine, Massachusetts, Oregon, and Rhode Island allowed individual municipalities to choose whether their public employees would be covered by the compensation law; Minnesota public employees were covered, except for employees of the state and employees of cities whose charters provided their own compensation schemes; Ohio exempted policemen and firemen in places where pensions were established; and, finally, Oklahoma and Washington limited coverage to public employees who were engaged in hazardous work. For further discussion of these intricate rules, see Clark and Frincke (1921, pp. 21-68).

16. The BLS also asked the families about the cost of their insurance, but only households that reported a positive value of insurance offered information on the cost of insurance. Thus we have no measure of insurance premiums for those households that bought zero. The mean cost of insurance among those who bought life insurance was about 12 cents per dollar of 
industrial life insurance, 6 cents per dollar of fraternal life insurance, 8 cents per dollar of old-line insurance, and 33 cents per dollar of accident insurance. The accident insurance costs were higher partly because accident insurance offered disability as well as life insurance.

17. We experimented with estimating separate probits for old-line life insurance, industrial life insurance, and fraternal insurance. The coefficient of expected benefits in each equation was small and statistically insignificant, just as we see when we aggregated all life insurance policies in Table 3.

18. We have also experimented with other specifications in the saving regression by adding an interaction term between the accident-rate measure and the expected benefits variable. The magnitudes of the effects estimated and the t-tests for the impact of expected benefits and accident risk is unchanged.

19. Fishback and Kantor (1994) find evidence that lumber and coal workers's wages experienced a compensating reduction in wages when post-accident benefits increased. One might argue that the fall in saving is purely a result of the decline in income when post-accident benefits rose. Note, however, that we already controlled for the income effect by including the worker's income in the saving function. Further, the average tradeoff Fishback and Kantor found was about a dollar-for-dollar tradeoff, while the saving effect is much larger than that at about 1.5 .

We have also recast the model to include the presence of compensating differentials in wages in response to the change in the post-accident payment $C$. In that case, the income $y$ can become a function of $\mathrm{C}, \mathrm{y}(\mathrm{C})$, where $\mathrm{y}^{\prime}(\mathrm{C})<0$. When insurance is unconstrained and relatively inexpensive $[p<1 /(1+r)]$, the more complicated model predicts that saving would rise whenever post-accident payments rise. When insurance is rationed, the model predicts that saving could either fall or rise when post-accident payments rise. Thus, even under 
compensating differentials, the only setting in which saving would be expected to fall with a rise in post-accident compensation is when there are limitations on the availability of insurance.

20. The predictions from the probits are the predictions of whether the worker had insurance or not. Problems with identification arising from using the same list of variables in the insurance instrument equations and the saving equation are eliminated by the nonlinearity of the probit predictions. We used the predictions rather than the observed values to avoid any problems with simultaneity bias arising from the fact that insurance is a choice variable in the model because workers could choose to purchase less than the insurance maximum.

21. Premium estimates are from the Cyclopedia of Insurance (1906, pp. 4 and 161; 1913, pp. 4 and 117; 1921, pp. 229-30, 287-88, and 465). Premiums collected for employers' liability insurance grew from $\$ 15.8$ million in 1905 to $\$ 36.8$ million in 1911 , an annual growth rate of 1.15 percent. Continued growth at that pace would have led to premiums of $\$ 129.5$ million in $1920, \$ 41.5$ million more than the actual level of employer's liability insurance of $\$ 86$ million. Premiums for accident insurance did not display the same shortfall. Premiums for accident insurance grew from $\$ 13.6$ million in 1905 to $\$ 18.8$ million in 1911 , a growth rate of 1.055 per annum. Continued growth at that pace leads to a prediction of $\$ 30.5$ million in 1920 , which equals the actual level of $\$ 30$ million. Employers' liability insurance still grew because interstate railroad workers were still under negligence liability, as were workers in several states. A better comparison would be to examine the changes in insurance within each workers' compensation state.

22. The results here do not necessarily imply that workers' compensation was a more efficient legal system than negligence liability, as far as workplace accidents are concerned. A worker consuming his desired level of insurance might not hold a socially optimal amount. Viscusi 
(1991, p. 82) notes that as workers reach their optimal levels of insurance, there may be increases in moral hazard, which raise the costs to insurers and employers. In fact, studies of accident rates and modern problems with fraudulent claims suggest that moral hazard problems have increased with the passage of workers' compensation (Fishback 1987; Moore and Viscusi 1990). A comparison of the relative efficiency of the two systems would require, at a minimum, a complete examination of the employers' and workers' costs of accident prevention, the damages incurred by injured workers, the administrative costs of the two systems, and other transaction and information costs. 


\section{REFERENCES}

Ackerman, S. B., Industrial Life Insurance (New York: Spectator Company, 1926).

Aetna Insurance Company, Annual Report, 1914.

Aetna Insurance Company, Classification of Risks for Accident Insurance (Hartford, 1919).

Clark, Lindley D., "The Legal Liability of Employers for Injuries to their Employees, in the United States," U.S. Bureau of Labor Bulletin No. 74 (January 1908).

Clark, Lindley D., and Martin C. Frincke, Jr. "Workmen's Compensation Legislation of the United States and Canada," U.S. Bureau of Labor Statistics Bulletin No, 272 (January 1921).

Conyngton, Mary K., "Effect of Workmen's Compensation Laws in Diminishing the Necessity of Industrial Employment of Women and Children," U.S. Bureau of Labor Statistics, Bulletin No. 217 (December 1917).

Cornelius, Martin P., Accidental Means: A Brief on the Insuring Clause of Personal Accident Policies (New York: Thomas A. Hine, 1920).

Cyclopedia of Insurance in the United States, 1911-1913 (Hartford: Insurance Journal Company, 1913).

Davis, Lance E., "The Investment Market, 1870-1914: The Evolution of a National Market," Journal of Economic History, 25 (Sept. 1965), pp. 355-99.

DeLeon, Edwin W., Manual of Liability Insurance (New York, 1907), pp. 26-27.

Dryden, John F., "Burial (or 'Industrial') Insurance," in Lester W. Zartman and William H. Price, eds., Personal Insurance: Life and Accident (New Haven, CT: Yale University Press, 1914), pp. 384-99.

Eastman, Crystal, Work-Accidents and the Law (New York: Charities Publication, 1910).

Epstein, Richard A., "The Historical Origins and Economic Structure of Workers' Compensation Law," Georgia Law Review, 16 (Summer 1982), pp. 775-819. 
Faulkner, Edwin J., Accident-and-Health Insurance (New York: McGraw-Hill, 1940).

Fefer, Mark D., "What To Do About Workers" Comp," Fortune (June 29, 1992).

Fishback, Price V., "Liability Rules and Accident Prevention in the Workplace: Empirical Evidence from the Early Twentieth Century," Journal of Legal Studies, 16 (June 1987), pp. 305-28.

Fishback, Price V., Soft Coal, Hard Choices (New York: Oxford University Press, 1992).

Fishback, Price V., and Shawn Everett Kantor, "Did Workers Pay for the Passage of Workers' Compensation Laws?" University of Arizona, Department of Economics Working Paper, 1994.

Fishback, Price V., and Shawn Everett Kantor, "Square Deal' or Raw Deal? Market Compensation for Workplace Disamenities, 1884-1903," Journal of Economic History, 52 (Dec. 1992), pp. 826-848.

Fisher, Willard C., "American Experience with Workmen's Compensation," American Economic Review, 10 (March 1920), pp. 18-47.

French, Will J., "The Trend of Workmen's Compensation--A Glance at Compensation History, Past and Present," Monthly Labor Review 11 (Nov. 1920), pp. 881-2.

Goldin, Claudia, "Family Strategies and the Family Economy in the Late Nineteenth Century: The Role of Secondary Workers," in Theodore Hershberg, ed., Philadelphia: Work. Space. and Group Experience in the Nineteenth Century (New York: Oxford University Press, 1981), pp. 277-310.

Gruber, Jonathan and Alan B. Krueger, "The Incidence of Mandated Employer-Provided Insurance: Lessons from Workers' Compensation Insurance," in David Bradford, ed., Tax Policy and the Economy (Cambridge, MA, 1991), pp. 111-143.

Haines, Michael R., "The Life Cycle, Savings, and Demographic Adaptation: Some Historical Evidence for the United States and Europe," in Alice S. Rossi, ed., Gender and the Life 
Course (New York: Aldine Publishing, 1985), pp. 43-63.

Hookstadt, Carl, "Comparison of Workmen's Compensation Laws of the United States Up to December 17, 1917," U.S. Bureau of Labor Statistics, Bulletin No. 240 (May 1918).

Hookstadt, Carl, "Comparison of Experience Under Workmen's Compensation and Employers' Liability Systems," Monthly Labor Review 8 (March 1919), pp. 230-248.

Hookstadt, Carl, "Comparison of Workmen's Compensation Laws and Administration, April 1922," U.S. Bureau of Labor Statistics Bulletin No. 301, (Washington, D.C., 1922).

Hookstadt, Carl, "Comparison of Workmen's Compensation Laws of the United States and Canada up to January 1, 1920," U.S. Bureau of Labor Statistics Bulletin No. 275, (Washington, D.C., 1920).

Insurance Research and Review Service (IRRS), Fraternal Life Insurance (Indianapolis: IRRS, 1938). Jones, F. Robertson, Digest of Workmen's Compensation Laws in the United States and Territories. with Annotations, revised to December 1, 1927, (New York: Workmen's Compensation Publicity Bureau, 1927.)

Keyssar, Alexander, Out of Work: The First Century of Unemployment in Massachusetts (New York: Cambridge University Press, 1986).

Kilgour, John G., "Workers' Compensation Problems and Solutions: The California Experience," Labor Law Journal, (Feb. 1992), pp. 84-96.

Kip, Richard De Raismes, Fraternal Life Insurance in America (Philadelphia: College Offset Press, 1953).

Kulp, C. A., Casualty Insurance (New York: Ronald Press Company, 1928).

Landes, William M., and Richard A. Posner, The Economic Structure of Tort Law (Cambridge, MA: Harvard University Press, 1987).

- Evidence for the Uníted States and Euröpe," in Alice S. Rössí, ed., Gendèr and the Life " 
(Fall 1967), pp. 254-279.

Minnesota Bureau of Labor, Industries and Commerce, Twelfth Annual Report. 1909-1910.

Modell, John, "Changing Risks, Changing Adaptations: American Families in the Nineteenth and Twentieth Centuries," in Allan J. Lichtman and Joan R. Challinor, eds., Kin and Communities: Families in America (Washington, DC: Smithsonian Institution Press, 1979), pp. $119-44$.

Moore, Michael J., and W. Kip Viscusi, Compensation Mechanisms for Job Risks: Wages, Workers' Compensation, and Product Liability (Princeton, NJ: Princeton University Press, 1990).

Nichols, Walter S., "Fraternal Life Insurance," in Lester W. Zartman and William H. Price, eds., Personal Insurance: Life and Accident (New Haven, CT: Yale University Press, 1914), pp. $361-83$.

Ohio Industrial Commission, The Ohio State Insurance Manual, Rules and Rates Effective July 1. 1923 (Columbus, OH, 1923).

Oregon Industrial Accident Commission, Second Report for the Two Year Period Ending June 30. 1917 (Salem, OR, 1919).

Priest, George L., "The Current Insurance Crisis and Modern Tort Law, " Yale Law Journal 96 (1987), pp. $1521+$.

Priest, George L., "The Modern Expansion of Tort Liability: Its Sources, Its Effects, and Its Reform," Journal of Economic Perspectives, 5 (Summer 1991), pp. 31-50.

Ransom, Roger L., and Richard Sutch, "Codebook and User's Manual: A Survey of 1,165 Workers in Kansas, 1884-1887. Reported in the First. Second. and Third Annual Reports of the Kansas Bureau of Labor and Industrial Statistics" (Berkeley, 1989).

Ransom, Roger L., and Richard Sutch, "Codebook and User's Manual: A Survey of 1,085 Workers in Maine, 1890. Reported in the Fifth Annual Report of the Maine Bureau of Industrial and 
Labor Statistics" (Berkeley, 1990).

Rotella, Elyce, and George Alter, "Working Class Debt in the Late Nineteenth Century United States," Journal of Family History 18 (Spring 1993), pp. 111-134.

Shapiro, Carl, "Symposium on the Economics of Liability," Journal of Economic Perspectives, 5 (Summer 1991), pp. 3-10.

Shavell, Steven, Economic Analysis of Accident Law (Cambridge, MA: Harvard University Press, 1987).

U.S. Bureau of the Census, Historical Statistics of the United States, Colonial Times to 1970 (Washington: GPO, 1975).

U.S. Bureau of the Census, Mortality Statistics, 1915-1920 (Washington: GPO, 1917-1922).

U.S. Bureau of Labor Statistics, "Workmen's Compensation Laws of the United States and Foreign Countries, December 23, 1913, Bulletin No, 126 (Washington: Govt. Pr. Off., 1914).

U.S. Bureau of Labor Statistics, "Workmen's Compensation Laws of the United States and Foreign Countries," U.S. Bureau of Labor Statistics Bulletin No. 203 (January 1917).

U.S. Bureau of Labor Statistics, "Workmen's Compensation Legislation in the United States and Foreign Countries, 1917 and 1918," U.S. Bureau of Labor Statistics Bulletin No. 243 (Washington, 1918).

U.S. Bureau of Labor Statistics, "Workmen's Compensation Legislation of the United States and Canada, 1920 to 1922," U.S. Bureau of Labor Statistics Bulletin No. 332 (Washington, June 1923).

U.S. Bureau of Labor Statistics, "Workmen's Compensation Legislation of the United States and Canada as of July 1, 1926," U.S. Bureau of Labor Statistics Bulletin No. 423 (Washington, 1926).

U.S. Department of Commerce and Labor, Twenty-Third Annual Report of the Commissioner of 
Labor, 1908 (Washington: GPO, 1909).

Viscusi, W. Kip, "Product and Occupational Liability," Journal of Economic Perspectives 5 (Summer 1991), pp. 71-91.

Viscusi, W. Kip, and Evans, William, "Utility Functions that Depend on Health Status:

Estimates and Economic Implications," American Economic Review 80 (June 1992), pp. 353-374.

Weinstein, James, "Big Business and the Origins of Workmen's Compensation," Labor History, 8 (Spring 1967), pp. 156-174.

Weiss, Harry, "Employers' Liability and Workmen's Compensation," in John R. Commons, ed., History of Labor in the United States. 1896-1932 (New York: Macmillan, 1935).

Whaples, Robert, and David Buffum, "Fraternalism, Paternalism, the Family, and the Market: Insurance a Century Ago," Social Science History, 41 (Apr. 1991), pp. 97-122.

Williamson, Jeffrey, and Peter Lindert, American Inequality: A Macroeconomic History (New York: Academic Press, 1980).

Wisconsin Industrial Commission, Annual Report (Madison, WI, 1915, 1916, 1917). 
Type of Insurance

Old-Line Life Insurance

Industrial Life Insurance

Fraternal Life Insurance

Establishment Life Insurance

Other Life Insurance

All Types of Life Insurance

All Types of Life Insurance Except Industrial

Accident Insurance
Percent of Households

Claiming One or More

Policy

$29.2 \%$

67.6

25.9

3.3

1.4

85.2

51.6

9.9

Notes: A number of households held multiple insurance policies. For example, 3.7 percent of the households (or 29.2 percent of the policy holders) held old-line insurance policies on more than one member of the household; 58.4 percent of the households (or 86.4 percent of the policy holders) held industrial life insurance on more than one member of the household; 6.9 percent of the households ( 26 percent of the policy holders) held fraternal life insurance on more than one member of the household; 0.1 percent of the households had establishment life insurance on more than one family member; and 0.6 percent held other life insurance on more than one family member.

Source: BLS, "Cost-of-Living in the United States, 1917-1919." Available through the InterUniversity Consortium for Political and Social Research, No. 8299. 
Table 2

\author{
Present Value of Expected Accident Benefits on \\ January 1, 1918, for a Worker Earning \$27.20 Per Week
}

\begin{tabular}{|c|c|c|c|c|c|}
\hline & Year in & $\begin{array}{l}\text { Expected } \\
\text { Benefits }\end{array}$ & & Year in & $\begin{array}{l}\text { Expected } \\
\text { Benefits }\end{array}$ \\
\hline State & Effect & in 1918 & State & Effect & in 1918 \\
\hline Alabama & 1920 & 2.53 & Montana & 1915 & 12.20 \\
\hline Alaska & 1915 & 18.42 & North Carolina & 1929 & 2.53 \\
\hline Arkansas & 1939 & 2.11 & North Dakota & 1919 & 6.33 \\
\hline Arizona & 1913 & 16.05 & Nebraska & 1913 & 15.98 \\
\hline California & 1911 & 20.59 & New Hampshire & 1912 & 12.97 \\
\hline Colorado & 1915 & 8.29 & New Jersey & 1911 & 11.42 \\
\hline Connecticut & 1914 & 15.87 & New Mexico & 1917 & 10.90 \\
\hline Delaware & 1914 & 11.77 & Nevada & 1913 & 23.76 \\
\hline Florida & 1935 & 4.43 & New York & 1910 & 23.16 \\
\hline Georgia & 1921 & 2.53 & Ohio & 1912 & 17.49 \\
\hline Hawaii & 1915 & 19.02 & oklahoma & 1915 & 10.38 \\
\hline Idaho & 1918 & 16.10 & Oregon & 1914 & 15.36 \\
\hline Illinois & 1912 & 16.94 & Pennsylvania & 1916 & 11.61 \\
\hline Indiana & 1915 & 16.32 & Rhode Island & 1912 & 14.96 \\
\hline Iowa & 1914 & 11.21 & South Carolina & 1935 & 2.53 \\
\hline Kansas & 1912 & 17.14 & South Dakota & 1917 & 12.89 \\
\hline Kentucky & 1916 & 13.81 & Tennessee & 1919 & 6.33 \\
\hline Louisiana & 1915 & 12.41 & Texas & 1913 & 19.28 \\
\hline Massachusetts & 1912 & 18.69 & Utah & 1917 & 15.66 \\
\hline Maryland & 1912 & 14.24 & virginia & 1919 & 4.11 \\
\hline Maine & 1916 & 12.26 & Vermont & 1915 & 11.70 \\
\hline Michigan & 1912 & 11.01 & Washington & 1911 & 14.27 \\
\hline Minnesota & 1913 & 14.39 & Wisconsin & 1911 & 15.23 \\
\hline Missour i & 1926 & 2.11 & West Virginia & 1913 & 12.19 \\
\hline Mississippi & 1948 & 3.80 & Wyoming & 1915 & 10.53 \\
\hline
\end{tabular}

Notes: The year reported above is the year in which workers' compensation first went into effect. Maryland (1902), Montana (1909) and Kentucky (1914) passed laws earlier that were declared unconstitutional. New York passed two laws in 1910. The compulsory law was declared unconstitutional, while the elective law was allowed to stand. A compulsory law went into effect in 1914. Maryland (1910) also passed a law specific to miners.

Source: The weekly wage of $\$ 27.20$ is the average weekly wage reported in the BLS Costof-Living Survey. The calculation of expected benefits assumes the worker has a wife aged 35 and children aged 8 and 10. The calculations follow the procedure described in Appendix A. 
Table 3

Coefricients from Probit Analyses of Accident and Life Insurance Coverage and OLS Estimation of Saving

\begin{tabular}{|c|c|c|c|c|c|}
\hline Variable & $\begin{array}{l}\text { Means } \\
\text { (Std. } \\
\text { Dev.) }\end{array}$ & $\begin{array}{l}\text { Life } \\
\text { Insurance } \\
\text { Purchased } \\
\{0,1\}\end{array}$ & $\begin{array}{l}\text { Accident } \\
\text { Insurance } \\
\text { Purchased } \\
\{0,1\}\end{array}$ & Saving & Saving \\
\hline Intercept & & $\begin{array}{l}0.287 \\
(0.16)\end{array}$ & $\begin{array}{r}-6.17 \\
(2.27)\end{array}$ & $\begin{array}{l}-338.6 \\
(2.04)\end{array}$ & $\begin{array}{l}-45.76 \\
(0.99)\end{array}$ \\
\hline $\begin{array}{l}\text { Present Value of } \\
\text { Expected Benefits }\end{array}$ & $\begin{array}{l}13.12 \\
(5.9)\end{array}$ & $\begin{array}{l}-0.006 \\
(1.30)\end{array}$ & $\begin{array}{l}-0.02776^{*} \\
(5.06)\end{array}$ & $\begin{array}{l}-1.557^{*} \\
(3.52)\end{array}$ & $\begin{array}{l}-1.207^{*} \\
(3.83)\end{array}$ \\
\hline Accident Risk & $\begin{array}{c}1.20 \\
(1.27)\end{array}$ & $\begin{array}{l}0.00095 \\
(0.05)\end{array}$ & $\begin{array}{c}-0.0188 \\
(0.92)\end{array}$ & $\begin{array}{l}2.011 \\
(1.18)\end{array}$ & $\begin{array}{l}1.67 \\
(0.99)\end{array}$ \\
\hline Age of Husband & $\begin{array}{l}36.9 \\
(8.5)\end{array}$ & $\begin{array}{l}0.017 \\
(1.07)\end{array}$ & $\begin{array}{l}-0.0057 \\
(0.31)\end{array}$ & $\begin{array}{l}2.15 \\
(1.37)\end{array}$ & $\begin{array}{l}2.26 \\
(1.44)\end{array}$ \\
\hline Age Squared & & $\begin{array}{c}-0.00019 \\
(0.95)\end{array}$ & $\begin{array}{l}0.00015 \\
(0.68)\end{array}$ & $\begin{array}{l}-0.004 \\
(0.20)\end{array}$ & $\begin{array}{l}-0.005 \\
(0.26)\end{array}$ \\
\hline $\begin{array}{l}\text { Husband's Annual } \\
\text { Earnings }\end{array}$ & $\begin{array}{r}1300 \\
(360)\end{array}$ & $\begin{array}{l}0.00012^{*} \\
(1.97)\end{array}$ & $\begin{array}{l}0.00043^{*} \\
(6.56)\end{array}$ & $\begin{array}{l}0.201^{*} \\
(35.15)\end{array}$ & $\begin{array}{l}0.201 * \\
(35.53)\end{array}$ \\
\hline $\begin{array}{l}\text { Wife's Annual } \\
\text { Earnings }\end{array}$ & $\begin{array}{c}19 \\
(74)\end{array}$ & $\begin{array}{l}-0.00018 \\
(0.71)\end{array}$ & $\begin{array}{l}0.00055 \\
(1.89)\end{array}$ & $\begin{array}{l}0.141^{*} \\
(5.66)\end{array}$ & $\begin{array}{l}0.137^{*} \\
(5.51)\end{array}$ \\
\hline $\begin{array}{l}\text { Net Income from } \\
\text { Rent and Interest }\end{array}$ & $\begin{array}{c}6 \\
(32)\end{array}$ & $\begin{array}{l}-0.0015^{*} \\
(3.02)\end{array}$ & $\begin{array}{l}0.00063 \\
(1.08)\end{array}$ & $\begin{array}{l}0.454^{*} \\
(8.16)\end{array}$ & $\begin{array}{l}0.450 \\
(8.08)\end{array}$ \\
\hline $\begin{array}{l}\text { Children's Annual } \\
\text { Earnings }\end{array}$ & $\begin{array}{c}87 \\
(273)\end{array}$ & $\begin{array}{l}0.00015 \\
(1.32)\end{array}$ & $\begin{array}{l}-0.00001 \\
(0.09)\end{array}$ & $\begin{array}{l}0.194^{*} \\
(17.79)\end{array}$ & $\begin{array}{l}0.193 * \\
(17.81)\end{array}$ \\
\hline $\begin{array}{l}\text { Income from Board } \\
\text { and Lodging }\end{array}$ & $\begin{array}{l}5.1 \\
(29.5)\end{array}$ & $\begin{array}{l}-0.00006 \\
(0.09)\end{array}$ & $\begin{array}{l}-0.0012 \\
(1.35)\end{array}$ & $\begin{array}{l}-0.156^{*} \\
(2.58)\end{array}$ & $\begin{array}{l}-0.156^{*} \\
(2.58)\end{array}$ \\
\hline $\begin{array}{l}\text { State Cost-of-Living } \\
\text { Index }\end{array}$ & $\begin{array}{l}100 \\
(5.1)\end{array}$ & $\begin{array}{l}-0.0022 \\
(0.13)\end{array}$ & $\begin{array}{l}0.00496 \\
(1.94)\end{array}$ & $\begin{array}{l}1.298 \\
(0.82)\end{array}$ & $\begin{array}{l}-1.64 \\
(4.61)\end{array}$ \\
\hline $\begin{array}{l}\text { Contributes to Union } \\
\text { Organization }\end{array}$ & $\begin{array}{c}0.320 \\
(0.47)\end{array}$ & $\begin{array}{l}-0.068 \\
(1.70)\end{array}$ & $\begin{array}{l}-0.087^{*} \\
(1.89)\end{array}$ & $\begin{array}{l}-13.96 * \\
(3.55)\end{array}$ & $\begin{array}{l}-13.49 * \\
(3.48)\end{array}$ \\
\hline Craft Occupation & $\begin{array}{l}0.489 \\
(0.50)\end{array}$ & $\begin{array}{l}0.151 \\
(3.05)\end{array}$ & $\begin{array}{l}0.032 \\
(0.53)\end{array}$ & $\begin{array}{l}4.56 \\
(0.93)\end{array}$ & $\begin{array}{l}4.36 \\
(0.89)\end{array}$ \\
\hline Operative Occupation & $\begin{array}{l}0.301 \\
(0.46)\end{array}$ & $\begin{array}{l}0.110 \\
(2.16)\end{array}$ & $\begin{array}{l}0.185^{*} \\
(2.05)\end{array}$ & $\begin{array}{l}-0.165 \\
(0.03)\end{array}$ & $\begin{array}{l}-0.618 \\
(0.12)\end{array}$ \\
\hline $\begin{array}{l}\text { Number of Children } \\
\text { Ages } 0 \text { to } 4\end{array}$ & $\begin{array}{l}0.917 \\
(0.87)\end{array}$ & $\begin{array}{l}-0.025 \\
(1.09)\end{array}$ & $\begin{array}{l}-0.0096 \\
(0.35)\end{array}$ & $\begin{array}{l}-16.99 * \\
(7.48)\end{array}$ & $\begin{array}{l}-17.45^{*} \\
(7.70)\end{array}$ \\
\hline
\end{tabular}




\begin{tabular}{|c|c|c|c|c|c|}
\hline $\begin{array}{l}\text { Number of Children } \\
\text { Ages } 5 \text { to } 9\end{array}$ & $\begin{array}{l}0.802 \\
(0.85)\end{array}$ & $\begin{array}{l}0.062^{*} \\
(2.71)\end{array}$ & $\begin{array}{l}-0.0398 \\
(1.51)\end{array}$ & $\begin{array}{l}-20.01^{*} \\
(9.06)\end{array}$ & $\begin{array}{l}-20.43^{*} \\
(9.26)\end{array}$ \\
\hline $\begin{array}{l}\text { Number of Children } \\
\text { Ages } 10 \text { to } 14\end{array}$ & $\begin{array}{l}0.567 \\
(0.80)\end{array}$ & $\begin{array}{l}0.004 \\
(0.16)\end{array}$ & $\begin{array}{l}0.0301 \\
(1.03)\end{array}$ & $\begin{array}{l}-26.48 * \\
(10.44)\end{array}$ & $\begin{array}{l}-26.67^{*} \\
(10.52)\end{array}$ \\
\hline $\begin{array}{l}\text { Number of Children } \\
\text { Ages } 15 \text { and Up }\end{array}$ & $\begin{array}{l}0.312 \\
(.71)\end{array}$ & $\begin{array}{l}-0.026 \\
(.58)\end{array}$ & $\begin{array}{l}-0.0418 \\
(0.80)\end{array}$ & $\begin{array}{l}-37.08^{*} \\
(8.34)\end{array}$ & $\begin{array}{l}-37.23^{*} \\
(8.39)\end{array}$ \\
\hline \multicolumn{6}{|l|}{ Regional Dummies } \\
\hline New England & $\begin{array}{l}0.12 \\
(0.32)\end{array}$ & $\begin{array}{l}0.649 \\
(6.30)\end{array}$ & $\begin{array}{l}-0.546 \\
(3.86)\end{array}$ & $\begin{array}{l}-5.08 \\
(0.50)\end{array}$ & \\
\hline MidAtlantic & $\begin{array}{l}0.19 \\
(0.39)\end{array}$ & $\begin{array}{l}0.731 \\
(8.69)\end{array}$ & $\begin{array}{l}-0.674 \\
(6.13)\end{array}$ & $\begin{array}{l}2.91 \\
(0.35)\end{array}$ & \\
\hline East North Central & $\begin{array}{l}0.22 \\
(0.41)\end{array}$ & $\begin{array}{l}0.521 \\
(3.80)\end{array}$ & $\begin{array}{l}-0.102 \\
(0.51)\end{array}$ & $\begin{array}{l}17.78 \\
(1.32)\end{array}$ & \\
\hline West North Central & $\begin{array}{l}0.09 \\
(0.28)\end{array}$ & $\begin{array}{l}0.418 \\
(3.74)\end{array}$ & $\begin{array}{l}-0.674 \\
(6.13)\end{array}$ & $\begin{array}{l}-6.63 \\
(0.59)\end{array}$ & \\
\hline South Atlantic & $\begin{array}{l}0.12 \\
(0.32)\end{array}$ & $\begin{array}{l}0.569 \\
(5.13)\end{array}$ & $\begin{array}{l}-1.09 \\
(7.53)\end{array}$ & $\begin{array}{l}-7.27 \\
(0.66)\end{array}$ & \\
\hline East South Central & $\begin{array}{l}0.06 \\
(0.24)\end{array}$ & $\begin{array}{l}0.482 \\
(3.75)\end{array}$ & $\begin{array}{l}-0.73 \\
(4.36)\end{array}$ & $\begin{array}{l}9.08 \\
(0.72)\end{array}$ & \\
\hline West South Central & $\begin{array}{l}0.05 \\
(0.21)\end{array}$ & $\begin{array}{l}0.283 \\
(1.91)\end{array}$ & $\begin{array}{l}-0.226 \\
(1.06)\end{array}$ & $\begin{array}{l}1.57 \\
(0.11)\end{array}$ & \\
\hline Mountain & $\begin{array}{l}0.05 \\
(0.23)\end{array}$ & $\begin{array}{r}0.021 \\
(.08)\end{array}$ & $\begin{array}{l}-0.58 \\
(1.44)\end{array}$ & $\begin{array}{l}-61.12 \\
(2.37)\end{array}$ & \\
\hline $\mathbf{N}$ & 7475 & 7475 & 7475 & 7475 & 7475 \\
\hline Adj. $R^{2}$ & & & & 0.215 & 0.213 \\
\hline $\begin{array}{l}\text { Means of Dependent } \\
\text { Variables }\end{array}$ & & $\begin{array}{l}0.852 \\
(0.36)\end{array}$ & $\begin{array}{l}0.10 \\
(0.30)\end{array}$ & $\begin{array}{l}72 \\
(173)\end{array}$ & $\begin{array}{l}72 \\
(173)\end{array}$ \\
\hline
\end{tabular}

Notes: Absolute values of t-statistics are in parentheses. Standard deviations are reported in parentheses below all means.

The craft dummy variable has a value of one for all workers listed as Craftsmen, Foremen, or Kindred Workers (coded numbers 300-398 in the 1940 Census' occupation codes, see note 12). The operatives dummy has a value of one for all workers listed as Operatives and Kindred Workers (codes 400-496). The category left out of the regressions is Laborers (codes 900-988). The BLS survey was 
taken during the period from August 1917 through February 1917, a period of substantial inflation. We have also run the analysis with the monetary values adjusted to constant dollars with Paul Douglas's Cost-of-Living Index $(1890-1899=100)$ as the deflator (U.S. Bureau of the Census, 1975, p. 212). The central results of the paper remain the same when the monetary variables are deflated.

Sources: "Cost-of-Living in the United States, 1917-1919," available through the InterUniversity Consortium for Political and Social Research, No. 8299. The accident risk measure matches each worker's industry with the workers' compensation premium paid per $\$ 100$ on the payroll by Ohio employers in 1923. The premiums are reported in Ohio Industrial Commission (1923). The expected benefits are calculated based on the procedure described in Appendix A. The cost-of-living index is calculated from Williamson and Lindert [1980, pp. 323-325]. They report a Koffsky-adjusted cost-of-living for the entire state including rural and urban areas, which was originally derived from urban cost-of-living indices. We reversed the formula to calculate the urban cost of living, by dividing the cost of living they report on p. 323-324 by $\left(1-a^{*} .065\right)$, where $a$ is the percentage of farm workers in the labor force and .065 is the percentage difference between the urban and rural cost of living. 


\section{Appendix A}

\section{Constructing the Expected Benefit Variable}

The expected benefit measure used in the wage regressions is essentially the probability of an accident multiplied by the present value of the stream of benefits paid to the worker if he were to experience an industrial accident. The calculation is more complicated because the worker could suffer a variety of accidents, each with a different probability and payout scheme. Workers' compensation commissions typically classified accidents into four broad categories: fatal, permanent total disability, permanent partial disability, and temporary disability. Permanent total disability accidents were relatively rare and the payments were very close to the fatal accident payouts, so we merged the permanent total disability and fatal accident categories together. Using the workers weekly earnings, we then calculated the benefits that would have been paid for a typical accident in each category. For the permanent partial disability category, we used the loss of a hand as a typical accident because the payment structure for the amputation of a hand was described in every law in every state. The typical accident in the permanent partial category, however, was actually much less serious. Based on actual accident statistics reported by the Wisconsin Industrial Commission [1915, p. $41 ; 1916$, p. $44 ; 1917$, pp. 6-7] for 1914 to 1917 , we found that the average payments for permanent partial disabilities was $\mathbf{2 1 . 9}$ percent of that for the loss of a hand. Thus, in computing our payment for a permanent partial accident, we scaled down the payout for the hand by multiplying the figure by 21.9 percent. We treated the typical temporary disability accident as putting workers out of work for 5 weeks. We then took the typical benefit in each category, multiplied by the per hour probability of an accident occurring in that category, and then summed across categories.

When calculating benefits in each category we took the statutory descriptions of the payments for accidents to a married worker with two children as the basis for our workers' compensation payment. We assumed the children were ages 8 and 10 and that the deceased's widow did not remarry and lived another 30 years. We obtained the statutory descriptions from various Bulletins of the United States Bureau of Labor Statistics in the Workmen's Compensation and Insurance Series [U.S. Bureau of Labor Statistics, 1914, 1917, 1918, 1923, and 1926; Hookstadt, 1920 and 1922; and Clark and Frincke, 1921] We also used Jones [1927]. When we needed to settle questions about the timing of changes in the law, the state's statutes were consulted directly. We based the features of the law on the situation as of January $1,1918$.

For fatal accidents, the typical law allowed weekly payments to be a percentage (up to 2/3) of the weekly wage for a specified period of time. We calculated the present value (using continuous discounting) of the stream of benefits using a discount rate of 10 percent. We chose 10 percent because we are looking at benefits from the workers' perspective. The calculations were sometimes complicated because states usually imposed maximums on the weekly payout or maximum total payouts. If the percentage times the weekly wage exceeded the maximum weekly payment, we inserted the maximum weekly payment into the present value calculations. In cases where there was a maximum total payment, we assumed the family received the regular weekly payment until the total undiscounted stream of payments reached the maximum total. Thus we determined the number of weekly payments by taking the maximum total divided by the weekly payment (states did not worry about discounting issues when deciding when a family reached its maximum total benefit).

For the loss of a hand, the typical state paid a percentage of the weekly wage for a fixed amount of time, subject to minimum and maximum weekly amounts. Some states commenced the hand payments after the worker collected a statutory amount of temporary disability pay. Following the recommendations of the International Association of Industrial Accident Boards and Commissions in 1920 (Hookstadt, 1920, p. 77), we assumed that the loss of a hand temporarily disabled the worker 
fully for 15 weeks before he could return to work. We calculated the present value of the stream of payments using continuous discounting. It was important to calculate the present value because some states would pay a relatively small amount per week for the rest of the worker's life. Without discounting the total amount paid would look quite large when in fact, the present value of the stream of payments was in the range seen for other states. In the few cases where a hand payment was not mentioned specifically, we followed the BLS in describing it as a 50 percent disability.

For temporary disabilities workers were paid a percentage of their weekly wage during the period of the disability, which we assumed to be 5 weeks. These payments were usually subject to minimum and maximum weekly amounts. Nearly all states had waiting periods. In many cases a worker injured for 5 weeks would receive no payment for the first 3 to 14 days of the disability, such that he might receive as few as 3 weekly payments. In a number of states, the worker would receive nothing during the waiting period, but if the disability lasted beyond 4 weeks (up to 7 weeks) the worker would eventually receive a retroactive payment for the first week or two of the disability. We have made our calculations sensitive to these nuances across states.

For the states without workers' compensation, based on material in Table $\mathbf{I}$ of Fishback and Kantor [1994], we assumed that the family of a worker killed in a workplace accident could expect to receive about half a year's income on average (taking into account the probability of getting nothing). We then calculated the payment for a hand to be $\mathbf{5 4 . 0 2}$ percent of the fatal accident benefit and for the 5-week disability to be 1.557 percent of the fatal accident benefit. These percentages were based on national averages of the ratios of hand to death benefits and disability to death benefits from all states during the year 1923. It is clear that the generosity of the liability systems varied across states because insurance companies established state differentials for employers' liability premiums in their ratebooks. The state differentials would typically reflect differences in the liability rules and differences in the court treatments of accident compensation. The differentials are reported in DeLeon [1907, pp. 26-27]. To make this calculation we multiplied the benefits above by the state's reported liability differential and then divided by 0.64333 . The 0.64333 was the average liability differential reported for the 46 states plus Arizona and New Mexico (which were territories in 1909) at that time. We also experimented with other payments under negligence liability. We tried giving a value of zero in the workers' compensation states and the results were basically unchanged.

The probabilities of an accident of each type were derived from different sources for each industry from the Oregon Industrial Accident Commission [1919, pp. 28-42]. The Commission reported the total number of accidents in each accident category and the number of full time workers covered under the workers' compensation system. 


\section{APPENDIX B}

\section{Comparative Statics for Insurance and Savings Variables with Respect to Changes in Post-Accident Compensation}

As described in the text, the objective function is

$Z(s, I)=U(n+y-p I-s)+(1-q) V(n+y+(1+r) s)+q W(n+C+I+(1+r) s)$.

The first order conditions for a maximum are

$$
\begin{aligned}
& Z_{1}=-U^{\prime}\left(x_{1}\right)+(1+r)(1-q) V^{\prime}\left(x_{2 n}\right)+q(1+r) W^{\prime}\left(x_{2 a}\right)=0 \text { and } \\
& Z_{1}=-p U^{\prime}\left(x_{1}\right)+q W^{\prime}\left(x_{2 a}\right)=0,
\end{aligned}
$$

where $x_{1}=n+y-p l-s, x_{2 n}=(1+r) s+C+I$, and $x_{2 n}=n+y+(1+r) s$.

The second order conditions for a maximum are

$$
\begin{aligned}
& Z_{2 s}=U^{\prime \prime}\left(x_{1}\right)+(1-q) V^{\prime \prime}\left(x_{2 n}\right)+q(1+r)^{2} W^{\prime \prime}\left(x_{2 a}\right)<0 \text { and } \\
& Z_{I I}=p^{2} U^{\prime \prime}\left(x_{1}\right)+q W^{\prime \prime}\left(x_{2 a}\right)<0 . \\
& Z_{w s} Z_{I I}-Z_{1 s}^{2}>0 \text {, where } \\
& Z_{1 s}=p U^{\prime \prime}\left(x_{1}\right)+q(1+r) W^{\prime \prime}\left(x_{2 a}\right)<0 \text { because } U^{\prime \prime}<0 \text { and } V^{\prime \prime}<0 .
\end{aligned}
$$

The comparative statics results for changes in saving and insurance when post-accident compensation changes ( $\mathrm{ds}^{*} / \mathrm{dC}$ and $\left.\mathrm{dr}^{*} / \mathrm{dC}\right)$ are

$$
\begin{aligned}
& \mathrm{ds} / \mathrm{dC}=\left(-\mathrm{Z}_{\mathrm{sc}} \mathrm{Z}_{\mathrm{II}}+\mathrm{Z}_{\mathrm{IC}} \mathrm{Z}_{\mathrm{lo}}\right) /\left(\mathrm{Z}_{\mathrm{w}} \mathrm{Z}_{\mathrm{II}}-\mathrm{Z}_{\mathrm{lo}}{ }^{2}\right) \text { and } \\
& \mathrm{dl}^{*} / \mathrm{dC}=\left(-\mathrm{Z}_{\mathrm{u}} \mathrm{Z}_{\mathrm{IC}}+\mathrm{Z}_{\mathrm{ac}} \mathrm{Z}_{\mathrm{ls}}\right) /\left(\mathrm{Z}_{\mathrm{us}} \mathrm{Z}_{\mathrm{ll}}-\mathrm{Z}_{\mathrm{ks}}{ }^{2}\right) \text {. }
\end{aligned}
$$

From the definition of a maximum and from the assumptions that $U^{\prime \prime}, V^{\prime \prime}$ and $W^{\prime \prime}$ are negative, the denominator of both functions is positive. Therefore, the sign of the numerator determines the direction of changes.

$$
\begin{aligned}
& Z_{s c}=q(1+r) W^{\prime \prime}\left(x_{2 a}\right)<0 \text { because } V^{\prime \prime}<0 \text { and } \\
& Z_{I C}=q W^{\prime \prime}\left(x_{2 a}\right)<0 \text { for the same reason. }
\end{aligned}
$$

Given this information, $-Z_{\mathrm{ac}} \mathrm{Z}_{\mathrm{II}}+\mathrm{Z}_{\mathrm{Ic}} \mathrm{Z}_{\mathrm{lu}}$ and $-\mathrm{Z}_{\mathrm{u}} \mathrm{Z}_{\mathrm{Ic}}+\mathrm{Z}_{\mathrm{ac}} \mathrm{Z}_{\mathrm{ls}}$ are both ambiguous in sign at first glance. If we substitute in the values of the derivatives, however, the signs of the above functions become more clear.

The sign of $d s^{*} / d C$ is determined by the sign of 


$$
-Z_{\mathrm{sc}} Z_{\mathrm{II}}+\mathrm{Z}_{\mathrm{Ic}} \mathrm{Z}_{\mathrm{ls}}=\mathrm{W}^{\prime \prime}\left(\mathrm{x}_{2 \mathrm{a}}\right) \mathrm{U}^{\prime \prime}\left(\mathrm{x}_{1}\right) \mathrm{q} \mathrm{p}(1-(1+\mathrm{r}) \mathrm{p}),
$$

which is determined by the sign of

$$
(1-(1+r) p) \text {. }
$$

This expression is positive as long as $p$ is less than $1 /(1+r)$.

The sign of $\mathrm{dI}^{*} / \mathrm{dC}$ is similarly affected by the relationship between $p$ and $1 /(1+r)$. Its sign is determined by the sign of

$$
\begin{aligned}
& -Z_{a c} Z_{1 C}+Z_{a c} Z_{1 s}= \\
& \quad W^{\prime \prime}\left(x_{2 a}\right) U^{\prime \prime} q(p(1+r)-1)-q(1-q)(1+r)^{2} W^{\prime \prime}\left(x_{2 a}\right) V^{\prime \prime}\left(x_{2 n}\right)
\end{aligned}
$$

Since the second term is negative, the whole term will be negative if

$$
\mathrm{p}(1+\mathrm{r})-1<0,
$$

When $\mathrm{p}$ is less than $1 /(1+\mathrm{r})$, the model predicts that $\mathrm{dI}^{*} / \mathrm{ds}$ is negative.

Thus, if the insurance premium $p$ is less than $1 /(1+r)$, we should expect that increases in postaccident compensation would lead to increases in saving and reductions in insurance purchases in the unrationed model.

Historically, $1 /(1+r)$ was probably no smaller than .9 because interest rates on saving rarely reached as high as 10 percent. Given that the probability of an accident was at most .2 and generally more like .02 , the insurance premium $p$ would have been much lower than .9 if insurance was actuarially fair. For the insurance premium $p$ to exceed $1 /(1+r)$ the load factor on insurance would have had to have been enormous or insurance was unavailable or rationed (in other words the premium at the margin was infinite). In fact, if $p$ exceeds $1 /(1+r)$, the worker could not achieve a maximum because the first-order conditions would never hold. From the first-order condition $Z_{1}=0, p / q U^{\prime}\left(x_{1}\right)=$ $W^{\prime}\left(x_{2 a}\right)$. Substitute this into the first-order condition $Z_{4}=0$ and simplify, then $U^{\prime}\left(x_{1}\right)[1-$ $(1+r) p]=(1+r)(1-q) V^{\prime}\left(x_{2 n}\right)$. By assumption $U^{\prime}, V^{\prime},(1+r)$ and $(1-q)$ must be positive; therefore, [1$(1+r)$ p] must be positive for the first-order conditions to hold.

If insurance is rationed, imposing impose binding constraints on the workers' purchases of insurance, we can rewrite the model as.

$X(s, I, u)=U(n+y-p I-s)+(1-q) V(n+y+(1+r) s)+q W(n+C+I+(1+r) s)+u(M-I)$, where $M$ is the maximum amount of insurance allowed by the insurance companies and $u$ is a LaGrangian multiplier.

The first order conditions for a maximum are

$$
\begin{aligned}
& X_{1}=-U^{\prime}\left(x_{1}\right)+(1+r)(1-q) V^{\prime}\left(x_{2 n}\right)+q(1+r) W^{\prime}\left(x_{20}\right)=0, \\
& X_{1}=-p U^{\prime}\left(x_{1}\right)+q W^{\prime}\left(x_{2 a}\right)-u=0
\end{aligned}
$$




$$
X_{u}=(M-I)
$$

The choice functions for insurance and saving derived from these first order conditions are now $s^{\mathbf{c}}=$ $s^{c}(y, n, r, p, q, C, M)$ and $F=\Gamma(y, n, r, p, q, C, M)$, and $u^{c}=u^{c}(y, n, r, p, q, C, M) . \quad \mathrm{X}_{w}, \mathrm{X}_{\mathrm{ll}}$, and $\mathrm{X}_{\mathrm{al}}$ are all negative (they are the same as the expressions the $Z_{u}, Z_{I l}$, and $Z_{a l}$ above). Also, $X_{a u}=0, X_{I u}=-1$, and $\mathrm{X}_{\mathrm{uu}}=0$.

The comparative statics show that increases in post-accident benefits $(C)$ lead to no effect on insurance purchases and lead workers to save less than before. The sign of $\mathrm{ds} / \mathrm{dC}$ is determined by the sign of

$$
X_{\mathrm{sc}}=q(1+r) W^{\prime \prime}\left(x_{2 a}\right),
$$

which is less than zero because $\mathrm{W}^{\prime \prime}$ is negative. The binding constraint on insurance purchases also leads to the result that insurance purchases are unaffected by changes in post-accident compensation $\left(\mathrm{dI}^{*} / \mathrm{dC}=0\right)$. However, this presumes that the insurance constraint remains binding. It is possible that the optimal level of insurance could fall below the constraint and then the impact of higher postaccident compensation would be to lower insurance purchases again.

We can also derive comparative statics for the impact on saving and insurance when insurance companies raise the maximum amount of insurance allowed. The impact on insurance $\left(\mathrm{dI}^{*} / \mathrm{dM}\right)$ is determined by the sign of $-X_{m}$, which is greater than zero; therefore, increases in the maximums lead workers to purchase more insurance. The impact on saving $(\mathrm{ds} * / \mathrm{dM})$ is determined by the sign of $X_{\mathrm{al}}$, which is negative; therefore, increases in the insurance maximum leads workers to save less.

The remaining comparative statics described in the text are summarized in Appendix Table 1. In the model where insurance companies impose a binding maximum on the workers, insurance purchases are unaffected by all the exogenous variables except the maximum itself. 


\section{Appendix Table 1}

Table of Comparative Statics

\section{Independent Variable}

Post-Accident Compensation (C)

\begin{abstract}
Accident risk (q)
Insurance premium (p)

Accident insurance and insurance premium jointly $(p=q)$
\end{abstract}

Income of head of household $(y)$

Income from other sources (n)

Interest rate on savings (r)

\section{Saving when} households can insure

plus

$?$

$?$

$?$

$?$

$?$

$?$

\section{Insurance when \\ households can insure}

minus

$?$

?

$?$

$?$

$?$

?
?

Saving when insurance is rationed

minus

\section{?}

minus

?

?

?

a The table shows the expected sign of the change in saving or insurance with respect to a change in the independent variables of the model. The comparative statics results are given for three models - 1) when saving (s) and insurance (I) are both available to the worker and are determined simultaneously; 2) when only saving is an option; and 3) when only insurance can be chosen. 